\title{
Acute Hepatitis E Virus Infection in Two Geographical Regions of Nigeria
}

\author{
I. M. Ifeorah, ${ }^{1}$ T. O. C. Faleye, ${ }^{2,3}$ A. S. Bakarey, ${ }^{4}$ M. O. Adewumi, ${ }^{3}$ A. Akere, ${ }^{5}$ \\ E. C. Omoruyi, ${ }^{6}$ A. O. Ogunwale, ${ }^{7}$ and J. A. Adeniji ${ }^{3}$ \\ ${ }^{1}$ Department of Medical Laboratory Sciences, Faculty of Health Science and Technology, College of Medicine, \\ University of Nigeria, Nsukka, Nigeria \\ ${ }^{2}$ Department of Microbiology, Faculty of Science, Ekiti State University, Ado Ekiti, Nigeria \\ ${ }^{3}$ Department of Virology, College of Medicine, University of Ibadan, Ibadan, Nigeria \\ ${ }^{4}$ Institute for Advanced Medical Research \& Training, College of Medicine, University of Ibadan, Ibadan, Nigeria \\ ${ }^{5}$ Department of Medicine, College of Medicine, University of Ibadan, Ibadan, Nigeria \\ ${ }^{6}$ Institute of Child Health, College of Medicine, University of Ibadan, Ibadan, Nigeria \\ ${ }^{7}$ Oyo State College of Agriculture and Technology, Igboora, Nigeria
}

Correspondence should be addressed to M. O. Adewumi; adewumil@hotmail.com

Received 23 August 2017; Accepted 23 November 2017; Published 13 December 2017

Academic Editor: Mario M. D’Elios

Copyright (C) 2017 I. M. Ifeorah et al. This is an open access article distributed under the Creative Commons Attribution License, which permits unrestricted use, distribution, and reproduction in any medium, provided the original work is properly cited.

\begin{abstract}
Hepatitis E virus (HEV) remains a major public health concern in resource limited regions of the world. Yet data reporting is suboptimal and surveillance system is inadequate. In Nigeria, there is dearth of information on prevalence of acute HEV infection. This study was therefore designed to describe acute HEV infection among antenatal clinic attendees and community dwellers from two geographical regions in Nigeria. Seven hundred and fifty plasma samples were tested for HEV IgM by Enzyme Linked Immunosorbent Assay (ELISA) technique. The tested samples were randomly selected from a pool of 1,115 blood specimens previously collected for viral hepatitis studies among selected populations (pregnant women, 272; Oyo community dwellers, 438; Anambra community dwellers, 405) between September 2012 and August 2013. One (0.4\%) pregnant woman in her 3rd trimester had detectable HEV IgM, while community dwellers from the two study locations had zero prevalence rates of HEV IgM. Detection of HEV IgM in a pregnant woman, especially in her 3rd trimester, is of clinical and epidemiological significance. The need therefore exists for establishment of a robust HEV surveillance system in Nigeria and especially amidst the pregnant population in a bid to improve maternal and child health.
\end{abstract}

\section{Introduction}

Hepatitis E virus (HEV) is a small, nonenveloped spherical particle of about $32-34 \mathrm{~nm}$ diameter and has a single stranded, positive sense RNA genome of approximately $7.5 \mathrm{~kb}$ that is surrounded by an icosahedral capsid [1]. It is the only member of the genus Hepevirus and has four genotypes capable of causing human infection $[2,3]$. Hepatitis E virus (HEV) infection is a major public health concern especially in sub-Saharan Africa among other developing countries $[4,5]$. It is one of the most common causes of acute hepatitis and jaundice in the world and has affected about one-third of the world's population [6]. Annually, about 20 million new cases and 33 million acute cases of HEV infection occur globally and HEV-related hepatic failure is responsible for approximately 56,600 deaths per year $[7,8]$.

While it is established that HEV transmission occurs predominantly via the fecal-oral route $[9,10]$, parenteral, personto-person, perinatal mode of transmission and eating undercooked wild boar, deer, and pork have also been suggested [11-14]. In developing countries, infection occurs both sporadically and as an epidemic, affecting a large proportion of the population [15].

In human population, prevalence of anti-HEV varies from one population to another, with significant increase noted among pregnant women and children $<2$ years old [4]. 


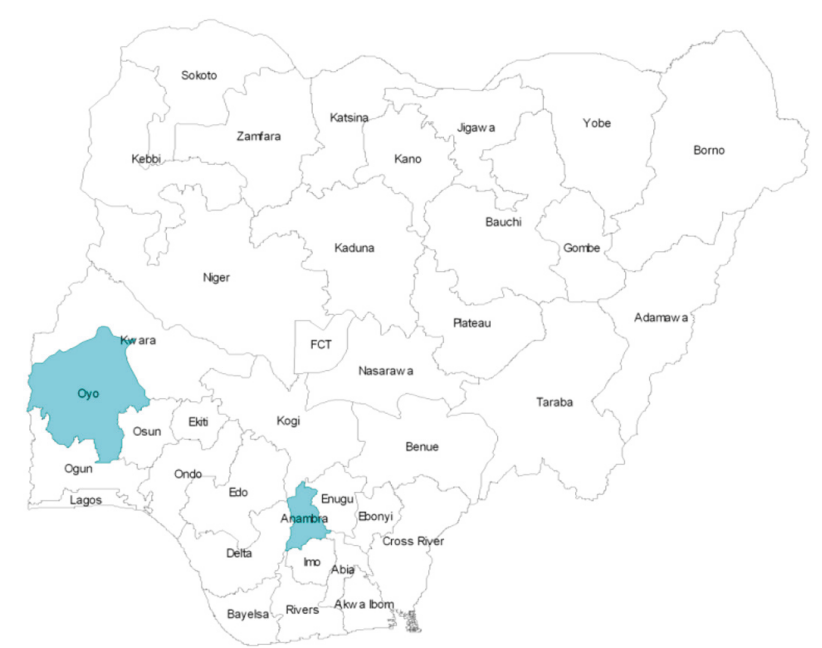

FIgURE 1: Map of Nigeria showing the study communities.

HEV infection is usually asymptomatic and self-limiting [16]; however, in some cases, acute infection may develop to fulminant hepatitis with high mortality especially among pregnant women in their third trimester [17], even as chronic forms of $\mathrm{HEV}$ have been documented among different populations [18-20]. Diagnosis of HEV infection is based on detection of anti-HEV IgM, anti-HEV IgG, and HEV RNA. Specifically, the presence of anti-HEV IgM is a marker of acute HEV infection [21].

Despite the significance of $\mathrm{HEV}$ in public health, especially in resource limited regions of the world, data reporting remained suboptimal, consequent of inadequate surveillance system [22]. In Nigeria, there exists dearth of information on prevalence and circulation of HEV infection in the population. In a bid to bridge this knowledge gap, we attempted, in this study, to describe acute HEV infection among selected population groups in two geographical regions in Nigeria.

\section{Methodology}

Seven hundred and fifty (750) plasma samples were randomly selected from a pool of 1,115 samples previously collected for viral hepatitis studies [23-27]. The 1,115 plasma samples were collected from consenting community dwellers and antenatal clinic attendees who participated in our previous studies conducted between September 2012 and August 2013. Specifically, the study populations include (1) pregnant women $(n=272)$ attending antenatal clinic in two different hospitals in Ibadan, Oyo state, Southwest, Nigeria, (2) community dwellers $(n=438)$ residing in and around Ibadan, Oyo state, Southwest, Nigeria, and (3) community dwellers $(n=405)$ from three selected communities in Anambra state, Southeast Nigeria (Figure 1). These samples were stored at $-86^{\circ} \mathrm{C}$ at the Department of Virology, College of Medicine, University of Ibadan, Nigeria. A total of 250 plasma samples per population were randomly selected to make the 750 samples analyzed in this study.
All samples were screened for HEV IgM using Enzyme Linked Immunosorbent Assay (ELISA) kits (Wantai Biological immunoassay, Beijing, China) with documented sensitivity and specificity of $97.10 \%$ and $98.40 \%$, respectively. Assays were performed according to manufacturer's instructions. Optical density was read using the Emax endpoint ELISA microplate reader (Molecular Devices, California, USA) and the results interpreted accordingly. Demographic and other relevant information were obtained from the participants using a well-structured questionnaire. Ethical approval for the study was granted by Ul/UCH Ethics committee (UI/UCH/1 1/0058), Oyo State Ministry of Health (A03/479/349), and Anambra State Ministry of Health (MH/PHD/MISC/1).

\section{Results}

In the pregnant women cohort (age range: $17-43$ years; median age: 29 years), one $(0.4 \%)$ participant had detectable $\mathrm{HEV}$ IgM. Majority (50\%) of the pregnant women, including the only positive participant, are within age group 31-40 years. Further analysis shows $2 \%, 44.8 \%$, and $3.2 \%$ for age groups $15-20,21-30$, and $41-45$ years, respectively (Table 1). Fortyfour (17.6\%), $74(29.6 \%)$, and $132(52.8 \%)$ of the pregnant women were in their 1st, 2nd, and 3rd trimester of gestation, respectively. It is noteworthy that the participant with detectable HEV IgM was in her 33rd week (3rd trimester) of gestation (Table 2).

Overall, the Ibadan community dwellers (age range: 1.5-87 years; median age: 40 years) and the Anambra communities' residents (age range: $15-70$ years; median age: 28.4 years) had zero prevalence rate for HEV IgM. Altogether, $70.8 \%$ and $29.2 \%$ of the Ibadan community dwellers were females and males, respectively. Further, the highest (25.6\%) and lowest (16.6\%) frequencies were recorded among age groups $21-30$ and $\leq 20$ years, respectively. For the Anambra residents, $54.8 \%$ were females, while $45.2 \%$ were males. Also, the highest $(29.6 \%)$ frequency was recorded in age group $21-30$ years, while age groups $\leq 20$ had the lowest $(0.05 \%)$ (Table 1).

\section{Discussion}

In this study, we report HEV IgM rate of $0.4 \%$ in the pregnant women cohort and zero prevalence rate among community dwellers in two different geographical regions of Nigeria. Our finding is in congruence with the rates of $0.9 \%$ reported in a study among different populations including apparently healthy individuals in Plateau state [28] but differs from $1.7 \%$ reported among ARV naïve and experienced HIV patients in Ibadan [29]. Though varied rates of HEV IgM have been reported in other endemic regions of the world among different populations [30-32]. The reasons for this discrepancy may range from variation in populations studied and test kits used among others.

Furthermore, wide variations in reported seroprevalence of HEV antibodies in Africa during nonepidemic periods of acute and symptomatic hepatitis have been documented [33]. Additionally, studies have indicated that commercially 
TABLE 1: Characteristics and HEV IgM prevalence among study participants.

\begin{tabular}{|c|c|c|c|c|c|c|}
\hline \multirow{2}{*}{ Variable } & \multicolumn{2}{|c|}{$\begin{array}{l}\text { Ibadan } \\
\text { pregnant women }\end{array}$} & \multicolumn{2}{|c|}{$\begin{array}{c}\text { Ibadan } \\
\text { general population }\end{array}$} & \multicolumn{2}{|c|}{$\begin{array}{c}\text { Anambra } \\
\text { general population }\end{array}$} \\
\hline & Frequency & $\begin{array}{c}\text { Percentage } \\
(\%)\end{array}$ & Frequency & $\begin{array}{c}\text { Percentage } \\
(\%)\end{array}$ & Frequency & $\begin{array}{c}\text { Percentage } \\
(\%)\end{array}$ \\
\hline \multicolumn{7}{|l|}{ Age } \\
\hline 20 and less & 5 & 2.0 & 28 & 11.2 & 41 & 16.4 \\
\hline $21-30$ & 112 & 44.8 & 81 & 32.4 & 64 & 25.6 \\
\hline $31-40$ & 125 & 50.0 & 74 & 29.6 & 51 & 20.4 \\
\hline $41-50$ & 8 & 3.2 & 37 & 14.8 & 47 & 18.8 \\
\hline 51 and above & - & - & 30 & 12.0 & 47 & 18.8 \\
\hline \multicolumn{7}{|l|}{ Sex } \\
\hline Male & - & - & 73 & 29.2 & 113 & 45.2 \\
\hline Female & 250 & 100 & 177 & 70.8 & 137 & 46.8 \\
\hline Total & 250 & 100 & 250 & 100 & 250 & 100 \\
\hline \multicolumn{7}{|l|}{ HEV IgM } \\
\hline Positive & 1 & 0.4 & 0 & 0 & 0 & 0 \\
\hline Negative & 249 & 99.6 & 250 & 100 & 250 & 100 \\
\hline \multicolumn{7}{|l|}{ Gestation age } \\
\hline 1st trimester & 44 & 17.6 & - & - & - & - \\
\hline 2nd trimester & 132 & 52.8 & - & - & - & - \\
\hline 3rd trimester & 74 & 29.6 & - & - & - & - \\
\hline
\end{tabular}

TABLE 2: HEV acute infection among the pregnant women.

\begin{tabular}{|c|c|c|c|c|c|c|c|c|c|}
\hline \multirow[b]{2}{*}{ Age } & \multicolumn{3}{|c|}{ 1st trimester } & \multicolumn{3}{|c|}{ 2nd trimester } & \multicolumn{3}{|c|}{ 3rd trimester } \\
\hline & Not tested & Not positive & $\begin{array}{c}\text { Not negative } \\
(\%)\end{array}$ & Not tested & Not positive & $\begin{array}{c}\text { Not negative } \\
(\%)\end{array}$ & Not tested & $\begin{array}{c}\text { Not positive } \\
(\%)\end{array}$ & $\begin{array}{c}\text { Not negative } \\
(\%)\end{array}$ \\
\hline 20 and less & 1 & 0 & $1(100)$ & 3 & 0 & $3(100)$ & 1 & 0 & $1(100)$ \\
\hline $21-30$ & 18 & 0 & $18(100)$ & 53 & 0 & $53(100)$ & 41 & 0 & $41(100)$ \\
\hline $31-40$ & 22 & 0 & $22(100)$ & 71 & 0 & $71(100)$ & 31 & $1(3.2)$ & $30(96.8)$ \\
\hline $41-50$ & 3 & 0 & $3(100)$ & 5 & 0 & $5(100)$ & 0 & 0 & 0 \\
\hline
\end{tabular}

available ELISA kits for anti-HEV antibodies differ dramatically in their sensitivity and specificity [34-36]. In our study, we used an ELISA kit that has been confirmed to have the highest diagnostic sensitivity and specificity when compared to many others by several studies $[35,37]$. Specifically, Vollerman et al. [38] in a comparative study to monitor HEV antibody seroconversion in asymptomatically infected blood donors using 9 different commercially available ELISA kits reported the best performance with the kit used in this study. Particularly, considerable variation for detection period of IgM antibodies was noted. Therefore, this implies that the prevalence rates of anti-HEV IgM recorded in this study are likely true representative of the study population as at the time of testing.

Results of this study might imply that the studied communities have good supply of clean water, as drinking of fecal contaminated water has been implicated as one of the major routes of $\mathrm{HEV}$ transmission [39]. Further, considering that $\mathrm{HEV}$ is known to cause acute infection [4], a study among asymptomatic persons may not capture acutely infected individuals who might be too sick to participate in such studies. However, this report does not underestimate the burden of acute HEV infection, especially, in resource limited countries as recent reports have confirmed outbreaks with dire consequences in different parts of sub-Saharan Africa including the Northern part of Nigeria [40, 41]. This therefore calls for the establishment of a robust surveillance system with focus on HEV that currently seems to be neglected.

The rate of $0.4 \%$ found among the pregnant women is in agreement with the rates of $0.5 \%, 0.6 \%$, and $0.67 \%$ reported among pregnant women in different regions of the world including Africa [42-44]. Our finding, though higher than $0 \%$ rate reported in a similar cohort in France [45], is lower than rates ranging from $2.6 \%$ to $33 \%$ recorded by several authors in a similar cohort in different regions of the world [46-50]. Variation in the performance of different ELISA kits employed in these studies may account for the difference in rates reported.

The fact that the only pregnant woman with HEV IgM in this study was in her 33rd week of gestation signifies a recent exposure to $\mathrm{HEV}$ and the medical significance of the 
case. The reason being that acute $\mathrm{HEV}$ in pregnancy can progress to fulminant hepatitis with a high mortality rate, especially, if it occurs in the 3rd trimester [17, 51]. Further, reports have shown that $\mathrm{HEV}$ infection during pregnancy can lead to maternal mortality rate of $15 \%$ to $25 \%$, especially, with genotype 1 , which together with genotype 2 are prevalent in the developing countries [52].

Acute HEV infection during pregnancy is associated with dire consequences for the unborn, including high rate of miscarriage, stillbirth, neonatal death, high risk of vertical transmission, and high risk of preterm delivery with poor neonatal survival rates $[51,53,54]$. It was reported that $\mathrm{HEV}$ infection might be responsible for 2,400 to 3,000 still births each year in developing countries, with many additional fetal deaths linked to antenatal maternal deaths [55]. It is worth mentioning that we do not have information on the outcome of this singular woman's pregnancy. Hence, we could not document the impact of the HEV infection in the $3 \mathrm{rd}$ trimester of pregnancy on either the mother or child.

Recent outbreaks of HEV infection have been documented among Nigerian refugees in Chad and in the Northern part of Nigeria with a significant number of pregnant women being affected [40, 41, 56]. With all the health challenges posed by acute HEV infection (especially among pregnant women) it is still grossly underreported in developing countries including Nigeria. For example, there are no laid down policies on HEV management in the country. The pregnant woman with detectable HEV IgM has documented report of fever and jaundice within the preceding 2 weeks prior sampling. Thus, it is probable that the symptoms were as a result of HEV infection, since the woman tested negative to other viral infections with the possibility of showing similar symptoms [23]. Laboratory screening for acute HEV infection is rarely done in Nigeria and more scarcely among pregnant women even when presenting with symptoms suggestive of hepatitis infection (especially when there is no outbreak). Routinely, $\mathrm{HBV}$ is the only hepatitis virus pregnant women are screened for in Nigeria. Therefore, it is safe to assume that screening for HEV IgM was not carried out for this woman at the antenatal clinic. Thus, she obviously might not have been managed for HEV infection. This brings to light how acute HEV infections are possibly missed despite its clinical and epidemiological implications for the subject and the population, respectively.

\section{Conclusion}

We documented acute HEV infection in a pregnant woman in Ibadan, Oyo State, Southwest Nigeria, and reported zero prevalence rates of acute $\mathrm{HEV}$ infection among community dwellers in two different locations in the country. Consequently, we recommend more extensive studies on $\mathrm{HEV}$ infection in the population in a bid to define the dynamics of this neglected viral infection. In addition, we recommend the introduction of HEV IgM screening for pregnant women in Nigeria. The public should be educated on HEV, its modes of transmission, and intervention strategies including vaccination in accordance with the WHO recommendations for safe vaccine [57].

\section{Conflicts of Interest}

The authors declare that they have no conflicts of interest.

\section{Authors' Contributions}

(a) I. M. Ifeorah, T. O. C. Faleye, M. O. Adewumi, and A. S. Bakarey were responsible for study design. (b) I. M. Ifeorah, M. O. Adewumi, E. C. Omoruyi, and A. Akere were responsible for sample collection. (c) I. M. Ifeorah and T. O. C. Faleye wrote first draft of the manuscript. (d) All authors were responsible for reagent acquisition and laboratory and data analysis, revised the manuscript, and read and approved the final draft.

\section{Acknowledgments}

The authors extend their sincere appreciation to Professor O. G. Ademowo of the Institute for Advanced Medical Research and Training (IAMRAT), College of Medicine, University of Ibadan, for providing laboratory space and equipment used at some point during the execution of this study. This study was carried out by the Evolutionary Dynamics of Hepatitis in Nigeria (EDHIN) research group. This study was not funded by any organization.

\section{References}

[1] S. U. Emerson and R. H. Purcell, "Hepatitis E Virus," in Fields Virology, D. M. Knipe and P. M. Howley, Eds., vol. 392, pp. 30473058, Lippincott Williams and Wilkins, Pennsylvania, Pa, USA, 5th edition, 2007.

[2] L. Lu, C. Li, and C. H. Hagedorn, "Phylogenetic analysis of global hepatitis E virus sequences: genetic diversity, subtypes and zoonosis," Reviews in Medical Virology, vol. 16, no. 1, pp. 536, 2006.

[3] S. Sridhar, S. K. P. Lau, and P. C. Y. Woo, "Hepatitis E: a disease of reemerging importance," Journal of the Formosan Medical Association, vol. 114, no. 8, pp. 681-690, 2015.

[4] E. Teshale and D. Hu, "Hepatitis E: epidemiology and prevention," World Journal of Hepatology, vol. 3, no. 12, pp. 285-291, 2011.

[5] N. Kamar, R. Bendall, F. Legrand-Abravanel et al., "Hepatitis E," The Lancet, vol. 379, no. 9835, pp. 2477-2488, 2012.

[6] J.-H. Kim, K. E. Nelson, U. Panzner, Y. Kasture, A. B. Labrique, and T. F. Wierzba, "A systematic review of the epidemiology of hepatitis E virus in Africa," BMC Infectious Diseases, vol. 14, no. 1, article 308, 2014.

[7] WHO, Hepatitis E, WHO fact sheet: No. 280, http://www.who .Int/mediacentre/factsheets/fs280/en/.

[8] F. Bazerbachi, S. Haffar, S. K. Garg, and J. R. Lake, "Extra- hepatic manifestations associated with hepatitis $\mathrm{E}$ virus infection: a comprehensive review of the literature," Gastroenterol Report, vol. 4, pp. 1-15, 2016.

[9] J.-P. Guthmann, H. Klovstad, D. Boccia et al., "A large outbreak of hepatitis E among a displaced population in Darfur, Sudan, 2004: the role of water treatment methods," Clinical Infectious Diseases, vol. 42, no. 12, pp. 1685-1691, 2006.

[10] C. M. Howard, T. Handzel, V. R. Hill et al., "Novel risk factors associated with hepatitis $\mathrm{E}$ virus infection in a large outbreak 
in Northern Uganda: results from a case-control study and environmental analysis," The American Journal of Tropical Medicine and Hygiene, vol. 83, no. 5, pp. 1170-1173, 2010.

[11] E. Boxall, A. Herborn, G. Kochethu et al., "Transfusion-transmitted hepatitis E in a nonhyperendemic country," Transfusion Medicine, vol. 16, no. 2, pp. 79-83, 2006.

[12] K. Matsubayashi, J.-H. Kang, H. Sakata et al., "A case of transfusion-transmitted hepatitis e caused by blood from a donor infected with hepatitis e virus via zoonotic food-borne route," Transfusion, vol. 48, no. 7, pp. 1368-1375, 2008.

[13] E. H. Teshale, S. P. Grytdal, C. Howard et al., "Evidence of person-to-person transmission of hepatitis e virus during a large outbreak in northern Uganda," Clinical Infectious Diseases, vol. 50, no. 7, pp. 1006-1010, 2010.

[14] M. El Sayed Zaki, A. A. El Aal, A. Badawy, D. R. El-Deeb, and N. Y. A. El-Kheir, "Clinicolaboratory study of mother-to-neonate transmission of hepatitis E virus in Egypt," American Journal of Clinical Pathology, vol. 140, no. 5, pp. 721-726, 2013.

[15] R. Aggarwal, "Hepatitis E: Epidemiology and Natural History," Journal of Clinical and Experimental Hepatology, vol. 3, no. 2, pp. 125-133, 2013.

[16] A. D. Fix, M. Abdel-Hamid, R. H. Purcell et al., "Prevalence of antibodies to hepatitis E in two rural Egyptian communities," The American Journal of Tropical Medicine and Hygiene, vol. 62, no. 4, pp. 519-523, 2000.

[17] S. K. Stoszek, M. Abdel-Hamid, D. A. Saleh, S. El Kafrawy, S. Narooz, Y. Hawash et al., "High prevalence of hepatitis E antibodies in pregnant Egyptian women," Transactions of the Royal Society of Tropical Medicine and Hygiene, vol. 10, pp. 95-101, 2006.

[18] A. I. Gonzalez Tallon, V. M. Vicente, M. L. M. Lindemann, and L. M. A. Justo, "Chronic hepatitis E in an immunocompetent patient," Journal of Gastroenterology and Hepatology, vol. 34, no. 6, pp. 398-400, 2011.

[19] B. Schlosser, A. Stein, R. Neuhaus et al., "Liver transplant from a donor with occult HEV infection induced chronic hepatitis and cirrhosis in the recipient," Journal of Hepatology, vol. 56, no. 2, pp. 500-502, 2012.

[20] C. Koenecke, S. Pischke, A. Heim et al., "Chronic hepatitis E in hematopoietic stem cell transplant patients in a low-endemic country?" Transplant Infectious Disease, vol. 14, no. 1, pp. 103106, 2012.

[21] N. Kamar, H. R. Dalton, F. Abravanel, and J. Izopet, "Hepatitis E virus infection," Clinical Microbiology Reviews, vol. 27, no. 1, pp. 116-138, 2014.

[22] D. A. Rayis, A. M. Jumaa, G. I. Gasim, M. S. Karsany, and I. Adam, "An outbreak of hepatitis E and high maternal mortality at Port Sudan, Eastern Sudan," Pathogens and Global Health, vol. 107, no. 2, pp. 66-68, 2013.

[23] T. O. C. Faleye, M. O. Adewumi, I. M. Ifeorah et al., "Detection of hepatitis B virus isolates with mutations associated with immune escape mutants among pregnant women in Ibadan, southwestern Nigeria," SpringerPlus, vol. 4, no. 1, pp. 1-8, 2015.

[24] T. O. C. Faleye, O. M. Adewumi, I. M. Ifeorah et al., "Detection and circulation of hepatitis B virus immune escape mutants among asymptomatic community dwellers in Ibadan, southwestern Nigeria," International Journal of Infectious Diseases, vol. 39, pp. 102-109, 2015.

[25] A. S. Bakarey, I. M. Ifeorah, T. O. C. Faleye et al., "B virus serological markers in a rural community in Southeastern Nigeria," British Journal of Medicine and Medical Research, vol. 21, no. 1, pp. 1-9, 2017.
[26] I. M. Ifeorah, A. S. Bakarey, M. O. Adewumi et al., "Patterns of serologic markers of hepatitis B virus infection and the risk of transmission among pregnant women in Southwestern Nigeria," Journal of Immunoassay and Immunochemistry, vol. 38, no. 6, pp. 639-651, 2017.

[27] A. S. Bakarey, I. M. Ifeorah, M. O. Adewumi, T. O. C. Faleye, A. Akere, E. C. Omoruyi et al., "Profiles of hepatitis B virus serological markers among asymptomatic population in anambra state, Southeastern Nigeria," Journal of Virology and Antiviral Research, vol. 6, no. 3, Article ID 1000178, 2017.

[28] S. A. Junaid, S. E. Agina, and K. A. Abubakar, "Epidemiology and associated risk factors of hepatitis $\mathrm{E}$ virus infection in Plateau State, Nigeria," Virology: Research and Treatment, vol. 5, pp. 15-26, 2014.

[29] G. N. Odaibo and D. O. Olaleye, "Hepatitis E Virus Infection in HIV Positive ART Naive and Experienced Individuals in Nigeria," World Journal of AIDS, vol. 03, no. 03, pp. 216-220, 2013.

[30] Z. M. El Sayed and W. Othman, "Role of hepatitis E infection in acute on chronic liver failure in Egyptian patients," Liver International, vol. 31, no. 7, pp. 1001-1005, 2011.

[31] F. Farshadpour, R. Taherkhani, and M. Makvandi, "Prevalence of hepatitis E virus among adults in south-west of Iran," Hepatitis Research and Treatment, vol. 2015, Article ID 759589, 5 pages, 2015.

[32] K. A. Traoré, J. B. Ouoba, H. Rouamba et al., "Hepatitis e virus prevalence among blood donors, Ouagadougou, Burkina Faso," Emerging Infectious Diseases, vol. 22, no. 4, pp. 755-757, 2016.

[33] M. De Paschale, C. Ceriani, L. Roman et al., "Epidemiology of hepatitis E virus infection during pregnancy in Benin," Tropical Medicine \& International Health, vol. 21, no. 1, pp. 108-113, 2016.

[34] J. Drobeniuc, J. Meng, G. Reuter et al., "Serologic assays specific to immunoglobulin $\mathrm{M}$ antibodies against hepatitis $\mathrm{E}$ virus: pangenotypic evaluation of performances," Clinical Infectious Diseases, vol. 51, no. 3, pp. e24-e27, 2010.

[35] J. J. Wenzel, J. Preiss, M. Schemmerer, B. Huber, and W. Jilg, "Test performance characteristics of anti-HEV IgG assays strongly influence hepatitis e seroprevalence estimates," The Journal of Infectious Diseases, vol. 207, no. 3, pp. 497-500, 2013.

[36] A. C. Shrestha, R. L. Flower, C. R. Seed, S. L. Stramer, and H. M. Faddy, "A comparative study of assay performance of commercial hepatitis E virus enzyme-linked immunosorbent assay kits in australian blood donor samples," Journal of Blood Transfusion, vol. 2016, Article ID 9647675, 6 pages, 2016.

[37] S. D. Pas, R. H. R. A. Streefkerk, M. Pronk et al., "Diagnostic performance of selected commercial HEV IgM and IgG ELISAs for immunocompromised and immunocompetent patients," Journal of Clinical Virology, vol. 58, no. 4, pp. 629-634, 2013.

[38] T. Vollerman, J. Diekman, M. Eberhardt, C. Knabbe, and J. Dreier, "Monitoring of anti-hepatitis E virus antibody seroconversion in asymptomatically infected blood donors: systematic comparison of nine commercial anti-HEV IgM and IgG assays," Viruses, vol. 8, no. 8, article 232, 2016.

[39] R. Aggarwal, D. Kini, S. Sofat, S. R. Naik, and K. Krawczynski, "Duration of viraemia and faecal viral excretion in acute hepatitis E," The Lancet, vol. 356, no. 9235, pp. 1081-1082, 2000.

[40] ProMED-mail, 2017, http://outbreaknewstoday.com/nigeria-ehepatitis-e-borno-state-cholera-kwara-state-84944/.

[41] ProMED-mail, 2017, https://www.voaafrique.com/a/au-moins30 -morts-de-1-hepatite-e-dans-e-sud-est-du-niger/3872514 .html. 
[42] M. L. M. Lindemann, G. Gabilondo, B. Romero, O. M. S. De La Maza, and M. T. Pérez-Gracia, "Low prevalence of hepatitis E infection among pregnant women in Madrid, Spain," Journal of Medical Virology, vol. 82, no. 10, pp. 1666-1668, 2010.

[43] G. Gu, H. Huang, L. Zhang, Y. Bi, Y. Hu, and Y.-H. Zhou, "Hepatitis $\mathrm{E}$ virus seroprevalence in pregnant women in Jiangsu, China, and postpartum evolution during six years," $B M C$ Infectious Diseases, vol. 15, no. 1, article 560, 2015.

[44] M. Abebe, I. Ali, S. Ayele et al., "Seroprevalence and risk factors of Hepatitis E Virus infection among pregnant women in Addis Ababa, Ethiopia," PLoS ONE, vol. 12, no. 6, p. e0180078, 2017.

[45] C. Renou, V. Gobert, C. Locher et al., "Prospective study of Hepatitis E Virus infection among pregnant women in France," Virology Journal, vol. 11, no. 1, article 68, 2014.

[46] A. A. Adjei, Y. Tettey, J. T. Aviyase et al., "Hepatitis E virus infection is highly prevalent among pregnant women in Accra, Ghana," Virology Journal, vol. 6, article 108, 2009.

[47] C. M. Goumba, E. R. Yandoko-Nakouné, and N. P. Komas, “A fatal case of acute hepatitis e among pregnant women, Central African Republic," BMC Research Notes, vol. 3, article 103, 2010.

[48] F. Huang, T. Ma, L. Li, W. Zeng, and S. Jing, "Low seroprevalence of hepatitis E virus infection in pregnant women in Yunnan, China," The Brazilian Journal of Infectious Diseases, vol. 17, no. 6, pp. 716-717, 2013.

[49] A. A. Ahumibe, G. Okonkwo, S. M. Shehu, E. N. Waziri, and P. Nguku, "Prevalence of hepatitis E markers in primary health care antenatal attendees in Abuja, Nigeria," International Journal of Infectious Diseases, vol. 21, article 397, 2014.

[50] W. Cong, J.-C. Sui, X.-Y. Zhang, A.-D. Qian, J. Chen, and X.$\mathrm{Q}$. Zhu, "Seroprevalence of hepatitis E virus among pregnant women and control subjects in China," Journal of Medical Virology, vol. 87, no. 3, pp. 446-450, 2015.

[51] M. T. Pérez-Gracia, B. Suay-García, and M. L. Mateos-Lindemann, "Hepatitis E and pregnancy: current state," Reviews in Medical Virology, vol. 27, no. 3, p. e1929, 2017.

[52] S. Ranger-Rogez, S. Alain, and F. Denis, "Hepatitis viruses: Mother-to-child transmission," Pathologie Biologie, vol. 50, no. 9, pp. 568-575, 2002.

[53] A. Ornoy and A. Tenenbaum, "Pregnancy outcome following infections by coxsackie, echo, measles, mumps, hepatitis, polio and encephalitis viruses," Reproductive Toxicology, vol. 21, no. 4, pp. 446-457, 2006.

[54] L. J. Krain, J. E. Atwell, K. E. Nelson, and A. B. Labrique, "Fetal and neonatal health consequences of vertically transmitted hepatitis E virus infection," The American Journal of Tropical Medicine and Hygiene, vol. 90, no. 2, pp. 365-370, 2014.

[55] S. Patra, A. Kumar, S. S. Trivedi, M. Puri, and S. K. Sarin, "Maternal and fetal outcomes in pregnant women with acute hepatitis E virus infection," Annals of Internal Medicine, vol. 147, no. 1, pp. 28-33, 2007.

[56] ProMED-mail, 2017, https://www.thecable.ng/hepatitis-e-killsfour-pregnant-women-borno-400-idps-infected.

[57] WHO Position Paper, "Hepatitis E Vaccine," Weekly Epidemiological Records, vol. 90, no. 18, pp. 185-200, 2015. 


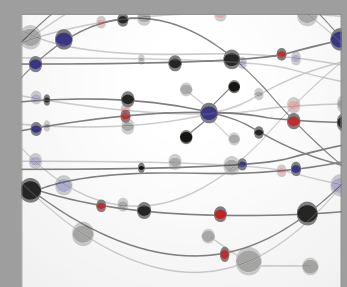

The Scientific World Journal
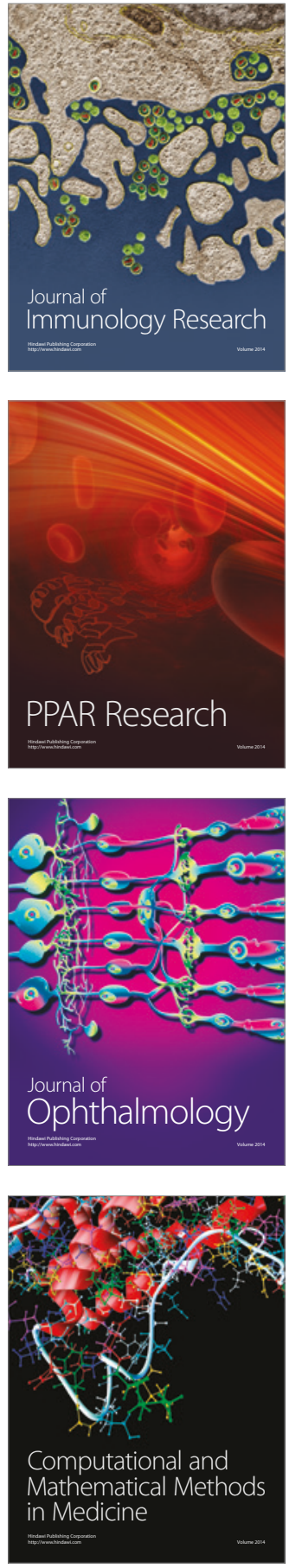

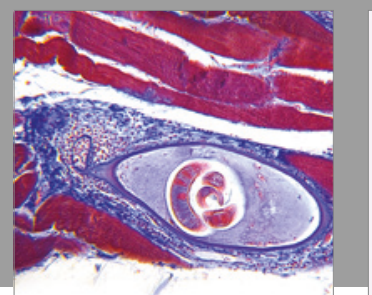

Gastroenterology Research and Practice
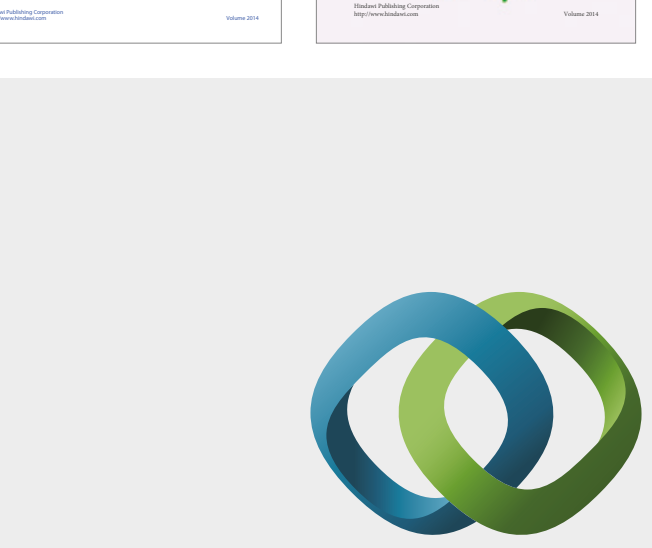

\section{Hindawi}

Submit your manuscripts at

https://www.hindawi.com
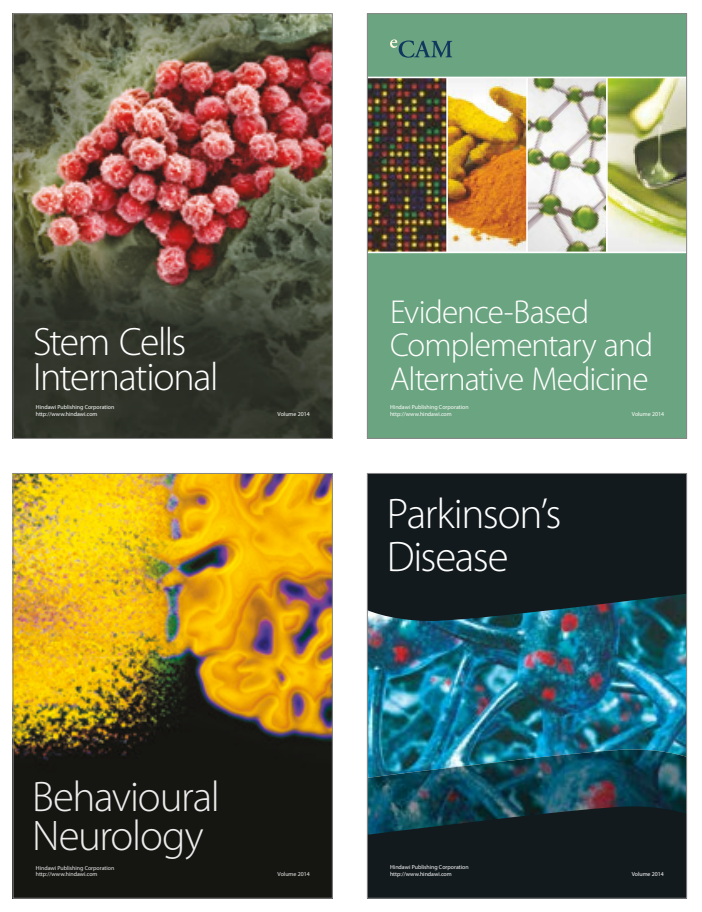
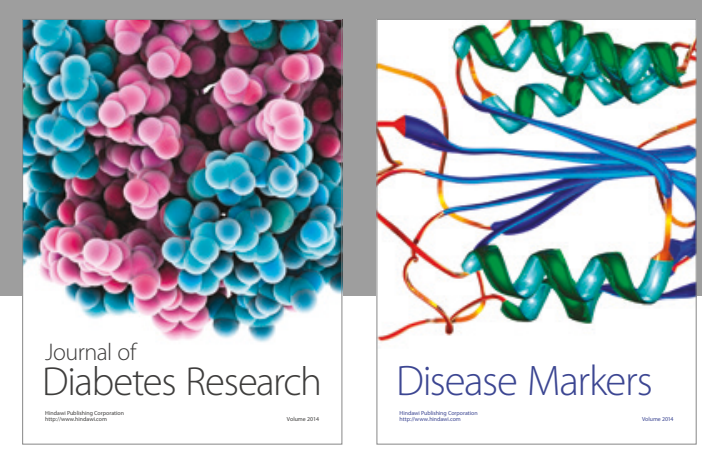

Disease Markers
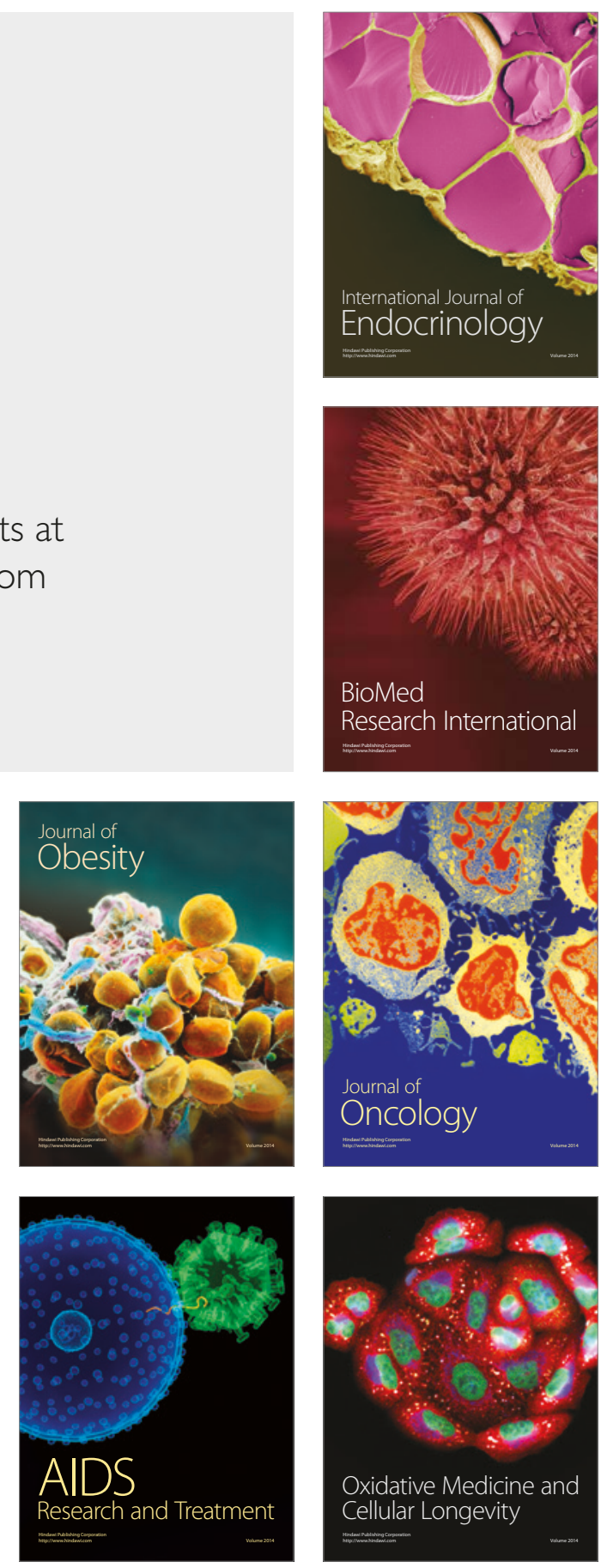